Meta

Journal des traducteurs

Translators' Journal

\title{
Censorship of Anime in Italian Distribution
}

\section{Ilaria Parini}

Volume 57, numéro 2, juin 2012

La manipulation de la traduction audiovisuelle

The Manipulation of Audiovisual Translation

URI : https://id.erudit.org/iderudit/1013948ar

DOI : https://doi.org/10.7202/1013948ar

Aller au sommaire du numéro

Éditeur(s)

Les Presses de l’Université de Montréal

ISSN

0026-0452 (imprimé)

1492-1421 (numérique)

Découvrir la revue

Citer cet article

Parini, I. (2012). Censorship of Anime in Italian Distribution. Meta, 57(2), 325-337. https://doi.org/10.7202/1013948ar

\section{Résumé de l'article}

Le contenu des anime - les dessins animés japonais - est transformé pour le rendre acceptable par le public. Cette pratique est utilisée fréquemment dans le monde occidental et l'Italie ne fait pas exception. Au Japon, les anime ne sont pas seulement conçus pour un public enfantin et l'on y trouve un grand nombre de produits destinés à des spectateurs d'âges variés. Par conséquent, dans ce pays, les anime sont diffusés, selon leur contenu, à des heures variables. Au contraire, en Italie, les dessins animés sont normalement perçus comme des produits destinés uniquement aux enfants. Ainsi, même lorsque les anime ont été au départ conçus pour un public d’âge plus mûr, ils sont diffusés dans des créneaux horaires protégés et doivent se soumettre à des normes précises de contenu et de niveau de langue. Les animes font donc l'objet d'une censure à la fois visuelle et verbale : les scènes que l'on considère inappropriées sont coupées, l'intrigue est souvent modifiée, les textes sont fréquemment "naturalisés ", tout particulièrement les références à la culture japonaise, et le langage est standardisé. Les traducteurs italiens jouent un rôle actif dans la modification du contenu des animes : comme ils sont les premiers à visionner les épisodes, ils doivent rapporter à leurs employeurs tout élément ambigu. Ils assurent donc une censure (ou autocensure) de type verbal, en manipulant le dialogue en fonction des exigences de l'agence de traduction.
Ce document est protégé par la loi sur le droit d'auteur. L'utilisation des services d’Érudit (y compris la reproduction) est assujettie à sa politique d'utilisation que vous pouvez consulter en ligne.

https://apropos.erudit.org/fr/usagers/politique-dutilisation/ 


\title{
Censorship of Anime in Italian Distribution
}

\author{
ILARIA PARINI \\ University of Milan, Milan, Italy \\ ilaria.parini@unimi.it
}

\section{RÉSUMÉ}

Le contenu des anime - les dessins animés japonais - est transformé pour le rendre acceptable par le public. Cette pratique est utilisée fréquemment dans le monde occidental et l'Italie ne fait pas exception. Au Japon, les anime ne sont pas seulement conçus pour un public enfantin et l'on y trouve un grand nombre de produits destinés à des spectateurs d'âges variés. Par conséquent, dans ce pays, les anime sont diffusés, selon leur contenu, à des heures variables. Au contraire, en Italie, les dessins animés sont normalement perçus comme des produits destinés uniquement aux enfants. Ainsi, même lorsque les anime ont été au départ conçus pour un public d'âge plus mûr, ils sont diffusés dans des créneaux horaires protégés et doivent se soumettre à des normes précises de contenu et de niveau de langue. Les animes font donc l'objet d'une censure à la fois visuelle et verbale: les scènes que l'on considère inappropriées sont coupées, l'intrigue est souvent modifiée, les textes sont fréquemment «naturalisés», tout particulièrement les références à la culture japonaise, et le langage est standardisé. Les traducteurs italiens jouent un rôle actif dans la modification du contenu des animes: comme ils sont les premiers à visionner les épisodes, ils doivent rapporter à leurs employeurs tout élément ambigu. Ils assurent donc une censure (ou autocensure) de type verbal, en manipulant le dialogue en fonction des exigences de l'agence de traduction.

\begin{abstract}
Editing of anime - Japanese cartoons - is a process through which the product is altered in order to make it appropriate for the public. Such a practice is quite common all over the Western world, and Italy is no exception. Japanese anime are not designed only for an audience of children, and there exist different types of products aimed at viewers of different ages; consequently, in Japan anime are shown at various time slots according to their characteristics. In Italy, on the contrary, cartoons are generally considered a product targeted exclusively at children, and even those anime which were originally designed for an older audience are broadcast during the protected time slot and therefore have to comply to certain standards regarding their content and the type of language spoken. Censorship thus tends to take place both on the visual and the verbal levels: scenes considered inappropriate are removed from the story, the plot is often changed, the text is frequently domesticated in its references to the Japanese culture, and the language is flattened. Italian translators take an active part in the editing of anime: as they are the first ones to actually see the episodes, they are supposed to report to their commissioners any ambiguous element they come across, and they perform (self)censorship on the verbal level, manipulating the dialogue exchanges as is expected by the translation company.
\end{abstract}

\section{MOTS-CLÉS/KEYWORDS}

anime, sous-titrage, censure, manipulation, naturalisation anime, dubbing, censorship, manipulation, domestication 


\section{Introduction}

As O'Hagan (2006: 242) observes, widespread popularity of Japanese popular cultural production of manga and anime beyond Japanese shores is evident in that these terms have entered the vocabulary of a growing international audience. Specifically, the term manga refers to Japanese graphic novels, while anime, an abbreviated pronunciation in Japanese of animation, is a term used to refer to Japanese cartoons. From a statistical point of view, Nakamura and Onouchi (2006: 30) reports that "in terms of international dissemination anime occupy $60 \%$ of the TV animation broadcast worldwide with the ratio in Europe exceeding 80\%."

The first anime were produced in Japan at the beginning of the $20^{\text {th }}$ century, and the first talkie anime, entitled Chikara to Onna Yo no Naka [Within the World of Power and Women], was directed in 1933 by Kenzō Masaoka (Baricordi, De Giovanni et al. 2000). However, it was only in the 1970s that the Western world started to import Japanese anime, which grew as a major cultural export during its market expansion in the 1980s and 1990s. Nowadays, Italy is one of the largest importers of anime, as Katan (2010: 12) notes. The scholar reports that on a single day, December 26,2009 , anime were broadcast for a total length of 135 minutes solely on Italian television channels Boing and Italia 1.

Even if in Western cultures cartoons are mainly considered a product targeted at an audience of children, the market of anime in Japan is extremely vast and competitive, and the products are aimed at a very heterogeneous public. This is the reason why there exist different types of anime, aimed at audiences of different ages, and which are even referenced with different names. For example, anime intended for children up to 10 years old are called kodomo, while shōnen are designed for male teenagers, and shōjo for female teenagers, seinen for male adults, and josei for female adults. In Japan there are proper broadcasting time slots for each age group, starting from the morning till late at night, and anime are shown during the various slots according to their characteristics. ${ }^{1}$

However, anime can be classified not only according to the target viewers' age group, since there are also various sub-genres within the genre. ${ }^{2}$ Even if, as Saito (1998, cited in Napier 2001: 117) has suggested, it is a fact that "anime can generally be divided into two categories, the 'country of boys' and the 'country of girls,' implying a very strong gender demarcation in the creation, targeting, narratives, and imagery of anime," it is also true that such animated products can be further divided into categories according to their specific narrative characteristics: for example, the cyberpunk, the mecha (shortening for the English word mechanical, which sees robots as main protagonists), the apocalyptic, the fantastic, the "body horror," the romantic comedy, the shōjo (which literally means little female and, besides indicating a product which is aimed at female teenagers, also refers to the main characters of this sub-genre), the sports club stories (spokon), the historical, the hentai (anime which include pornography), the so-called yaoi (anime with homoerotic or homoromantic male themes), and the yuri (anime focusing on love - either sexual or simply emotional - among female characters) (see note 1).

In spite of all the distinct peculiarities which characterize the various categories, anime are usually considered simply as generic cartoons aimed at children in most of the countries which import these series for TV broadcasting purposes. In fact, 
they are very often broadcast during the protected time slot, ${ }^{3}$ notwithstanding the original intended age of the target audience. This is primarily due to economic reasons, as the advertising of products and gadgets related to such cartoons is generally undertaken during the afternoon slot. Consequently, the products shown have to comply to certain standards regarding content and language. This presupposes that anime have to be edited, which is quite common in many countries. Editing refers to a process whereby the product is altered in order to be made appropriate for the foreign audience and it includes censoring of visual as well as audio content.

Despite the several studies dedicated to the historical relationship between censorship and translation (Billiani 2007; Fawcett 2003; Jansen 1995; Ní Chuilleanáin, Ó Cuilleanáin et al. 2008; Rundle 1999; 2000; 2010; Rundle and Sturge 2010; Sturge 1999; 2002), as well as to censorship and film studies (Grieveson 2004; Mathews 1994), and also to censorship and audiovisual translation (Bucaria 2009; Gambier 2002; Parini, forthcoming; Pavesi and Malinverno 2000), and despite the growing body of literature on anime produced by scholars working on Asian, cultural, and film studies (Brown 2008; Napier 2005; Nakamura and Onouchi 2006), virtually no attention has been devoted in academia to the manipulation and censorship of the products belonging to this genre during the process of translation. In fact, the only documented reports that can be found regarding this extremely common phenomenon are usually provided by anime fans (the so-called otaku), who complain about the alteration of these programmes in dedicated websites or forums.

Since the practice of editing anime is quite the norm also in Italian distribution, this study will attempt to describe the various forms of censorship that are performed in this specific market in order to make the product appropriate for broadcasting on TV. Curiously enough, series released directly for the DVD market are usually not altered, and some series with edited television versions may also have DVD uncut versions.

\section{Censorship on the visual level}

As far as the visual code is concerned, editing and censorship take place for various reasons, which leads to the alteration of the actual images in order to make them appropriate for the audience.

\subsection{Nudity and sexuality}

Anime which are originally targeted at an audience of teenagers sometimes contain scenes which may be considered as vaguely erotic. Even if scenes of explicit sex are definitely rare in this category of anime, it is not so uncommon to see young female characters partially or fully naked. This is not accepted in many Western countries which have regulations regarding child pornography that forbid showing any images of undressed children during the protected time slot. Nudity is consequently censored. However, the ways of editing these scenes differ from country to country. In the US, for example, usually the scenes are made more acceptable by operating directly on the visual code in order to mitigate the images. For instance, in the US release of Bishōjo senshi Sèrā Mūn (1992-1997), Sailor Moon (1995-1997a), ${ }^{4}$ the lines tracing the breasts of the female characters were airbrushed. ${ }^{5}$ 
In Italian distribution, however, these scenes tend to be simply removed, which is easier and also less expensive, although in some cases images are modified in Italy as well. In the last episode of Sailor Moon, for instance, the protagonist of the series was shown completely naked, and the Italian distributors decided to cover the breasts and pubic area of the character with the juxtaposition of other images. ${ }^{6}$

\subsection{Violence and blood}

Several studies (Huesmann and Eron 1986; Huesmann and Moise 1996; Murray 1997) have argued that exposure to violence through media, especially during childhood, can have damaging effects on the spectators, who may become desensitized to violence and prone to aggressiveness. For this reason, anime which are imported in Western countries to be shown to a young audience are often altered to remove violence, death, blood, and the use of weapons. This is achieved in various ways: sometimes blood and weapons are painted out or airbrushed, or the screen may be flashed in scenes which are considered violent, such as the moment of a physical blow (typical in the case of martial arts). Some other times, however, violent scenes are simply cut out, as in the American editions of Doragon Bōru (1986-1989), Dragon Ball (2001-2003) ${ }^{7}$ and Doragon Bōru Zetto (1989-1996), Dragon Ball Z (1996-2003) ${ }^{8}$ (Phoenix 2006: 22). There are also cases when whole episodes may be removed from a series, as happened in an episode of the American distribution of the Pokemon (1997-ongoing), Pokémon (1998-ongoing), ${ }^{9}$ entitled Miniryū no Densetsu [The Legend of Dratini], in which there was a prolific use of guns pointed at and shot at characters. ${ }^{10,11}$ Usually, in Italy, violent scenes are simply cut out, as in the series Sureiyazzu (1995; Slayers 1997), ${ }^{12}$ NARUTO (2002-2007; Naruto 2002-2008), ${ }^{13}$ Burū Doragon (2007-2008; Blue Dragon 2009), ${ }_{1}^{14}$ and the aforementioned Pokémon (2000-ongoing; see note 9), which tends to be the easiest and also cheapest solution. ${ }^{15}$ However, there are also cases when editing has occurred on the visual level, as with the Naruto series (see note 13), where blood was coloured in brown or black, or a scene involving an injured character was shown in black and white to mask the wound. ${ }^{16}$ Also, in the Italian version of the series Saint Seiya (1986-1989), Cavalieri dello Zodiaco (19901992), ${ }^{17}$ blood-spattered scenes were either removed or airbrushed. ${ }^{18}$

\section{Censorship on the verbal level}

Alteration on the verbal level may be performed for different reasons and in several cases, which vary from having to change the plot to make it more palatable for the target audience, to policies of domestication (Venuti 2008), to requirements to make the language comply to certain expected canons.

\subsection{Plot modification}

Sometimes the plot is changed in dubbing through dialogue. This may happen for a number of reasons. For example, the age of the characters is occasionally changed and made a few years older, and consequently also the level of the school they attend is altered accordingly. This is due to the fact that quite often the characters have love relationships or are involved in situations which are considered more suitable to 
somewhat older individuals. This is the case, for example, of the series Kädokyaputa Sakura (1998-2000), where the age of the protagonist was changed in the Italian version (Pesca la tua carta Sakura 1998-2001) from 10 to 14 years old. ${ }^{19,20,21}$

In the Italian version of Dr. Suranpu (1981-1986), Dr Slump \& Arale (1983-2006), ${ }^{22}$ a character called Aoi, who was actually the elder sister of Akane, one of the main characters, was turned into her mother, as apparently it was not appropriate for a young girl to live with her sister. The problem arose when the actual character of Aoi's and Akane's mother appeared in one of the last episodes of the series. The question was solved through dialogue alterations and the girls' mother became simply a different relative.

Plot modification is sometimes also performed to avoid ambiguities in the relationships between characters of the same sex which might be interpreted as homosexual. Indeed, it is not uncommon to find allusions of this kind in Japanese anime (especially in series classifiable as yaoi and yuri), but Italian distributors tend to get rid of any such references. In the anime Card Captor Sakura, for example, the character of Tomoyo is clearly in love with Sakura (both female characters), just like Touya is with Yukito (both male characters). In the Italian dubbed version of the anime all these relationships - which were considered to be inappropriate for an audience of children - have been turned into innocent friendships through dialogue alterations (see note 21 ).

Also the anime Sailor Moon turned out to be a difficult case for the Italian editors. The fifth series of the anime was accused by the Italian psychologist Vera Slepoj of seriously compromising the sexual identity of young spectators (Pellitteri 2002: 270; D'Agostino 2005). The therapist had received complaints by some parents of male children who apparently identified with the protagonist. The debate was further exacerbated by the fact that in the series there were three characters, the Sailor Starlights, who in normal circumstances looked and acted like men, while when they were fighting were transformed into women. Transformations of this kind are a quite common phenomenon in Japanese anime, which is usually referred to as henshin (Napier 2005: 49-62, 148-150). In the Italian adaptation the problem deriving from this gender ambiguity was solved by giving each male fighter a twin female sibling, therefore turning the three characters into six.

\subsection{Domestication of cultural references}

Cultural streamlining in the editing of anime is quite common in Western distribution, where references to Japanese culture are usually domesticated, in order to make the product familiar to the audience. In American distribution in particular, this process is very common and sometimes implies not only the verbal code, but also the visual one. Indeed, American editing often involves the substitution of Japanese elements with references drawn from American pop-culture, such as food. In the Pokémon series, for example, onigiri (small snacks made up of rice balls and containing a centre of plum) were variously referred to as donuts or sandwiches, and sometimes this kind of manipulation also implied alteration of the visual code (see note 11). Moreover, American editing tends to delete any Japanese writing or inserts which occur on the screen and replace them with English text, therefore operating on the visual code once again (see note 10). 
Italian editing does not seem to always follow the same policy. In the case of Japanese writings (for instance, with street or shop signs, maps, newspapers, billboards and the like), it once used to be quite common to eliminate them, resorting to the use of freeze frames. An example of this policy can be observed in the Italian version of the anime Efu (1988), $F$ (1991), ${ }^{23}$ in which every single text that appeared on the screen written in Japanese characters was removed. ${ }^{24}$ Nowadays, however, Italian distributors have become more tolerant in this respect, and they tend to keep the original written items as they are. In the case of verbal references to Japanese realia, such as food, Italian dubbing quite often domesticates them, especially if they are not clearly visible on the screen, replacing them with Italian food realia or elements which belong to Western tradition and are easily recognizable by an Italian audience (i.e., hamburgers, chips, sandwiches, and the like). In any case, even when these elements are clearly visible on screen, nowadays it is preferred not to interfere with the visual code, unless strictly necessary, as it can be quite expensive to modify the images. Another distinctive feature of Italian distribution is the fact that very often the names of the characters are changed and given Italianised, Americanised or invented names which are thought to be more easily pronounceable by Italian viewers and dubbing actors. For example, in Pesca la tua carta Sakura (1998-2001; see note 19), Chiharu was changed into Ciaro, Toyua into Toy, and Yukito into Yuki, while in Dragon Ball (2000-2001; see note 8) Uron became Oscar, Ranchi was called Laura, and Pikkoro was turned into Junior.

\subsection{Addition of dialogue exchanges}

As with most audiovisual programmes, Japanese anime also present moments of silence which may last several seconds. In these cases some American, as well as Italian, distributors often opt for adding extra information in the form of dialogue. ${ }^{25}$ This is, for example, the case of the anime Dragon Ball $Z$ or Saint Seiya: Knights of the Zodiac (see notes 8 and 17). In both these series, moments of silence before fight scenes, where the characters are sizing up their opponents, tend to be manipulated. In the Italian adaptation, these silences are filled with a voiceover adding new information about these moments. The comments are invented tout court as they are not present in the original. The same thing sometimes happens in the climax of love scenes, or particularly tragic moments. As a result, the tension linked to the moment tends to be spoiled, and anime fans have often complained about this procedure. ${ }^{26}$

\subsection{Flattening of language}

Since violence and death are considered topics that can have a destabilizing effect on young spectators, as already seen in the section about censorship performed on the visual level, references to them tend to be prime candidates for censorship on the verbal level. Words related to the semantic field of death, for example, are to be avoided. In Italy, verbs such as uccidere and ammazzare [to kill, to murder] are commonly translated with euphemisms such as eliminare, mandare all'altro mondo [to eliminate, to send to the other world]. Even more neutral verbs such as morire and spirare [to die, to pass away] are not easily tolerated and the strategy is to render them through their more delicate and vague synonyms andarsene, passare a miglior 
vita [to go away, to pass to a better life]. The consequence in some cases is that a character who has actually died in the original programme might simply be "gone away" in Italian, although where this person has gone is often a mystery.

Since the use of words such as morte [death] and morire [to die] is not tolerated by the commissioners, especially Mediaset, also verb phrases such as morire di fame [to starve] or morire di sete [to be parched] are avoided and replaced by expressions such as avere una fame/sete da lupi/cani [to be hungry/thirsty like a wolf/dog], while to be dead tired, which would normally be translated as morire di sonno and essere stanco morto, becomes avere un sonno da ghiro [be as sleepy as a dormouse].

In addition, mentions of blood are not accepted. In these cases it is more difficult to find a proper euphemism to replace its referent; therefore, and whenever possible, the reference is simply omitted. Nonetheless, when avoiding the reference proves impossible, translators may make use of expressions such as liquido corporeo [body fluid]. Likewise, drugs tend not to be mentioned either, and in Italian dubbing they are usually referred to as sostanze sospette [suspicious substances].

Needless to say that vulgar and strong expressions and interjections are also subject to changes and manipulation. This, however, can sometimes be taken to extremes, as the only expressions or interjections allowed are unlikely neutral utterances that no one would ever use in real life, not even small children. Examples of admissible expressions are accipicchia, acciderba, acciderbolina, perdindirindina (all of which would approximately correspond to the English blimey). Even the expression accidenti [damn], which is not vulgar at all, but is slightly more likely to occur in spontaneous spoken language, is forbidden by certain commissioners.

Insults represent another element which is usually not allowed. While in the original anime the characters might exchange verbal offences, which would correspond to English idiot, stupid or dumb, in Italian dubbing these terms are softened and the worst abuses likely to be mentioned are improbable phrases such as testa di legno [wooden head] and testa di rapa [turnip head], which, again, would not be used in authentic oral production.

Therefore, it is clear how the tendency to delete or tone down references revolving around potentially disturbing elements such as violence and death, and to censor swearwords and vulgarities, which has been ascertained in various studies on Italian dubbing (Bucaria 2009; Parini, forthcoming; Pavesi and Malinverno 2000), reaches extreme levels in the case of anime.

\section{The translator's role}

Italian translators take an active part in the editing of anime. First of all, translators are most often the first ones to actually see the episodes. In fact, commissioners tend to purchase anime series without previously visioning them, mainly on the basis of the success of their manga version on the Italian market, or following their favourable reception in other countries. Therefore, translators are supposed to report to the artistic director of the dubbing company any ambiguous or unpleasant elements they come across, so that they are later removed or altered during the post-production phase. Moreover, translators are responsible for performing censorship on the verbal level, manipulating the language as is indicated by the commissioners.

Anime translators who start working in Italian dubbing companies are usually instructed by their senior colleagues about the "code of rules and guidelines" that 
they are supposed to follow. It is a code that is orally transmitted from one translator to the other, for which there does not exist a written version, but which is considered as a sort of "translators' Bible." In essence, it consists of a list of indications related to how they are expected to behave when translating anime.

The first thing to be taken into account is that anime are generally translated into Italian via English. In fact, translators are given the video of the episode in Japanese, accompanied by a written script in English, which is the translation of the original Japanese. The problem, however, is that an enormous quantity of information has been, as the title of a famous film goes, "lost in translation" or, in any case, somewhere along the process. In fact, it is not uncommon for the characters on the screen to speak for ten or even twenty seconds, while the script would just read something short and innocuous like Good morning, sir. This is the reason why people doing this job are not just called "translators," but also "adapters," and even "dialogue writers." It is a fact that they literally have to invent whole lines, to make them fit with the movements of the characters' lips, because even if we are talking about cartoons, where the lips' movements are not as precise and distinct as in films starring human actors, and especially in the case of anime, which are often produced using the technique of limited animation, which implies fewer frames than traditional animation, it goes without saying that the isochrony, i.e., the length of the lines and the pauses, has to be respected as much as possible (Díaz Cintas and Orero 2010).

When it comes to series such as Meitantei Konan (1996-ongoing; American edition: Case Closed 2004-2009; Italian edition: Detective Conan 2002-ongoing), ${ }^{27}$ the translating can indeed become quite problematic. This anime tells the stories of a teenage detective, Shinichi Kudo, who is forced by some criminals to drink a potion which makes him shrink into a child of about 7 years. Shinichi then has to live his life accordingly, and in order to hide his real identity he adopts the name Conan Edogawa. Under his new identity, he continues to help the police solve mysterious cases, just as he used to do before being turned into a child. Each episode usually presents a murder case that the protagonist eventually solves.

From these presuppositions it is easy to understand how translators can find themselves in quite a challenging situation. In every single episode they would have to refer to murders, murderers, killers, homicides, manslaughters, corpses, blood, and bloodsheds, without using any of the Italian equivalents for such words. All direct references to the indicted referents ought to be avoided, or expressed by resorting to all sorts of euphemisms, such as colpevole [guilty] for murderer or homicide, the extremely vague term fatto [fact] for murder or killing, and corpo [body] for corpse. The word sangue [blood] should not be mentioned, and that becomes a major challenge, as quite often Conan manages to solve the case thanks to a series of traces of blood. In such cases the translators should avoid the direct reference as much as possible, and use a generic reference to traces, stains or spots of an unknown - or, in any case, unmentioned - substance.

Such vagueness quite often results in a lack of clarity throughout the story. However, series translated according to these criteria succeed in meeting the expectations of the commissioners since they avoid the risk of arousing protests from associations of young spectators' parents, especially by Moige (Movimento Italiano Genitori), concerned with the protection of their children's psychological balance and well-being. 


\section{A changing situation?}

For many years, Italian fans have been protesting in various ways against the manipulative editing of anime and in 1997 a group of them founded the association ADAM (Associazione Difesa Anime \& Manga Italia - Italian Association for the Defence of Anime \& Manga). This association maintains close relationships with some experts in the field and for over ten years has been actively engaged in the fighting against the manipulation and censorship of Japanese animation, mainly through the Internet.

The protests aired by the association seem to have achieved some results. Indeed, in recent years it has been possible to observe some changes in the attitudes of distributors. Until a few years ago watching unaltered programmes on terrestrial TV channels was only possible on MTV, which has always followed the policy of broadcasting uncut anime at night, during the non protected time slots, preceded by a warning about their content. Some satellite channels might broadcast cartoons targeted at adults at night as well.

However, the most important changes have occurred in Mediaset channels, and especially Italia 1, the channel which commissions and broadcasts the highest number of anime. Even if most of the series keep being altered and manipulated to different extents, so that they can be shown during the afternoon, in recent years some anime have been broadcast in their uncensored versions at night, as for instance the film Steamboy (2008; Italian version of Suchimubōi 2004), ${ }^{28}$ and some films of the series Capitan Harlock (L'Arcadia della mia giovinezza 2000; Italian version of Kyaputen Hārokku: Waga Seishun no Arukadia 1982), ${ }^{29}$ and Lupin III (Un diamante per sempre 2007; Italian version of Rupan sansei: Otakara Henkyaku Dai-sakusen!! 2003). ${ }^{30}$ Moreover, nowadays the use of words such as assassino [murderer], uccidere [to kill], morto [dead], and sangue [blood] seems to have become more tolerated, as is evident in the latest seasons of Detective Conan (2002-ongoing; see note 27). ${ }^{31}$

The state television RAI, on the other hand, quit broadcasting Japanese anime in the 1970s, after the major success of the first famous series UFO Robo Gurendaiza (1975-1977; UFO Robot Goldrake 1978-1980; known in Italy as Goldrake and in the United States and the United Kingdom as Grendizer), ${ }^{32}$ and has opted for showing Disney productions instead. However, in 2000-2001 they broadcast at night hours some films of the Dragon Ball Z series and in 2008 the anime film Il castello errante di Howl (2004; Italian version of Hauru no ugoku shiro 2004). ${ }^{33}$ Moreover, in 2009 the new channel Rai4 started broadcasting uncensored new anime entitled Code Geass: Lelouch of the Rebellion (2009-2010; Italian version of Kōdo Giasu - Hangyaku no Rurūshu 2006-2007), ${ }^{34}$ Code Geass: Lelouch of the Rebellion R2 (2009-2010; Italian version of Kōdo Giasu - Hangyaku no Rurūshu R2 2008), ${ }^{35}$ and Sfondamento dei cieli Gurren Lagann 2009-2010; Italian version of Tengen toppa Guren Ragan 2007). ${ }^{36}$

In sum, it is possible to state that the situation is changing, if only slowly and gradually. However, it is important to acknowledge that the ardent fans of the genre seem to have their voices heard and to have achieved some small yet important results in their fight against manipulation. It is also worthwhile underlining the fact that associations such as ADAM Italia (which is part of an international net consisting of analogous groups, such as ADAM Spain, or Save Our Sailors in the USA) do not aim simply at the preservation of the integrity of anime in their dubbed and post-produced versions. They are also fully aware of the pressures that the distributors suffer 
because of the continuous attacks by associations of parents, who are worried about the exposure of their children to what they consider inappropriate programmes. What fans want is that distributors show more respect towards the products they import and acknowledge their real nature in the translation and the images that are sold in Italian. Their ultimate aim is to persuade Italian distributors to do in Italy what Japanese distributors do in Japan: show anime in different time slots according to their characteristics. However, the way to get there still seems to be a very long, arduous one. The economic advantages related to the merchandising of the gadgets aimed at young children undoubtedly plays an extremely important role in the process of decision making, which closely relates to the actual editing of the anime. Therefore, translators will presumably have to wait some more time before they can offer a translation which better reflects the content of the original programme.

\section{NOTES}

1. Anonymous (2004; Last update: 2011): Storia e Spiegazioni delle Censure degli anime (cartoni animati) in Italia - Che cosa sono le «censure»? Visited on 30 June 2012, <http://win.ilbazardimari. net/censure/spiegazioni/articolo01.html>.

2. For a more detailed analysis of the peculiarities of anime and its sub-genres see Baricordi, De Giovanni et al. (2000), Brown (2008), and Napier (2001; 2005).

3. The protected time slot was established in Italy in 1997 within a code of self-regulation signed by the main national television organisations, RAI and Mediaset. It refers to the period of time from 7 am to $10: 30 \mathrm{pm}$, when children might presumably be watching television and therefore should be "protected" from viewing audiovisual programmes which may be inappropriate for people of a young age, who are supposedly more sensitive towards and impressionable by certain topics than adults.

4. Bishōjo senshi Sērā Mūn (1992-1997): Directed by Junichi Sato. Japan. Sailor Moon (1995-1997a): American version of Bishōjo senshi Sērā Mūn (1992-1997).

Sailor Moon (1995-1997b): Italian version of Bishōjo senshi Sērā Mūn (1992-1997).

5. Wheeler, Robert, Bednarski, Dan and Gould, Tiffany (2000; Last update: 15 March 2012): Sailor Moon Uncensored. Visited on 20 February 2011, <http://www.smuncensored.com>.

6. Marialuisa, G. (2003; Last update: March 2012): Le censure di Sailor Moon - Le censure dell'ultimo episodio. Visited on 20 February 2011, <http://win.ilbazardimari.net/censure/cartoni/sailormoon/ ultimoepisodio.html>.

7. Doragon Bōru (1986-1989): Directed by Daisuke Nishio and Minoru OкаZaki. Japan.

Dragon Ball (2001-2003): American version of Doragon Bōru (1986-1989).

Dragon Ball (1989-1998): Italian version of Doragon Bōru (1986-1989).

8. Doragon Bōru Zetto (1989-1996): Directed by Daisuke Nishio. Japan. Dragon Ball Z (1996-2003): American version of Doragon Bōru Zetto (1989-1996).

Dragon Ball Z (2000-2001): Italian version of Doragon Bōru Zetto (1989-1996).

9. Pokemon (1997-ongoing): Directed by Masamitsu Hidaka and Norihiko Sudo. Japan.

Pokémon (1998-ongoing): American version of Pokemon (1997-ongoing).

Pokémon (2000-ongoing): Italian version of Pokemon (1997-ongoing).

10. Aeschliman, Lesley (2012): Censorship in anime. Visited on 20 February 2011, <http://www.bellaonline.com/articles/art66773.asp>.

11. Anonymous (2002; Last update: 2012): Pokemon anime censorship. Visited on 20 February 2011, $<$ http://www.psypokes.com/anime/censor.php $>$.

12. Sureiyāzu (1995): Directed by Takashi WatAnABE. Japan. Slayers (2002): American version of Sureiyāzu (1995).

Slayers (1997): Italian version of Sureiyāzu (1995).

13. NARUTO (2002-2007): Directed by Hayato DATE. Japan. Naruto (2005-2009): American version of NARUTO (2002-2007).

Naruto (2002-2008): Italian version of NARUTO (2002-2007).

14. Burū Doragon (2007-2008): Directed by Yukihiro Matsushita. Japan. Blue Dragon (2008-2010): American version of Burū Doragon (2007-2008). Blue Dragon (2009): Italian version of Burū Doragon (2007-2008). 
15. Marialuisa, G. (2003; Last update: March 2012): Esempi di censure in anime e manga. Visited on 20 February 2011, <http://win.ilbazardimari.net/censure/esempi.html>.

16. Marialuisa, G. (2003; Last update: March 2012): Le censure di Naruto. Visited on 20 February 2011, <http://win.ilbazardimari.net/censure/cartoni/naruto/censure_generali.html>.

17. Saint Seiya (1986-1989): Directed by Yasuhito Kikuchi and Kozo Morishita. Japan. Saint Seiya: Knights of the Zodiac (2003): American version of Saint Seiya (1986-1989). Cavalieri dello Zodiaco (1990-1992): Italian version of Saint Seiya (1986-1989).

18. Anonymous (n.d.): Anime no censura - Saint Seiya. Visited on 20 February 2011, $<$ http://www.animenocensura.org/Saint\%20Seiya/Episodi\%20Censurati\%20Saint\%20Seiya\%20-\% 20Prima\%20Parte.php>.

19. Kādokyaputā Sakura (1998-2000): Directed by Morio AsAKA. Japan. Cardcaptor Sakura (2000-2001): American version of Kādokyaputā Sakura (1998-2000). Pesca la tua carta Sakura (1998-2001): Italian version of Kādokyaputā Sakura (1998-2000).

20. Anonymous (n.d.): Anime no censura - Card Captor Sakura. Visited on 20 February 2011, <http:// www.animenocensura.org/Card\%20Captor\%20Sakura/Card\%20Captor\%20Sakura.php>.

21. Marialuisa, G. (2003; Last update: March 2012): Le censure di Card Captor Sakura - Censure generali. Visited on 20 February 2011, <http://win.ilbazardimari.net/censure/cartoni/card_captor_sakura/censure_generali.html>.

22. Dr. Suranpu (1981-1986): Directed by Minoru Oкаzaki. Japan. Dr Slump \& Arale (1983-2006): Italian version of Dr. Suranpu (1981-1986).

23. Efu (Japan 1988): Directed by Koichi Mashimo. Japan. $F$ (1991): Italian version of Efu (1988).

24. Marialuisa, G. (2003; Last update: March 2012): Il Giappone? Non esiste! Visited on 20 February 2011, <http://win.ilbazardimari.net/censure/spiegazioni/censura03.html>.

25. Interestingly, in Italy such a practice is common not only in the dubbing of Japanese anime or of cartoons in general, but also of films, and even in the case of films d'auteur, as Galassi explains when discussing his versions of Rohmer's films (Licari and Galassi, 1994).

26. Marialuisa G. (2003; Last update: March 2012): Premessa alle censure - I dialoghi aggiuntivi. Visited on 20 February 2011, <http://win.ilbazardimari.net/censure/spiegazioni/articolo01.html>.

27. Meitantei Konan (1996-ongoing): Directed by Gôshô Aoyama. Japan. Case Closed (2004-2009): American version of Meitantei Konan (1996-ongoing). Detective Conan (2002-ongoing): Italian version of Meitantei Konan (1996-ongoing).

28. Suchìmubōi (2004): Directed by Katsuhiro Отомо. Japan. Steamboy (2005): American version of Suchìmubōi (2004). Steamboy (2008): Italian version of Suchìmubōi (2004).

29. Kyaputen Hārokku: Waga Seishun no Arkadia (1982): Directed by Tomaharu Katsumata. Japan. Captain Harlock: Arcadia of my Youth (2003): American version of Kyaputen Härokku: Waga Seishun no Arukadia (1982).

Capitan Harlock: L’Arcadia della mia giovinezza (1987): Italian version of Kyaputen Hārokku: Waga Seishun no Arukadia (1982).

30. Rupan sansei: Otakara Henkyaku Dai-sakusen!! (2003): Directed by Jun Kagawoe. Japan. Lupin III: Operation Return the Treasure (2003): American version of Rupan sansei: Otakara Henkyaku Dai-sakusen!! (2003).

Lupin III: Un diamante per sempre (2007): Italian version of Rupan sansei: Otakara Henkyaku Dai-sakusen!! (2003).

31. Marina Mocetti Spagnuolo, translator/adapter of several anime series and ex colleague of mine, has confirmed this tendency, which was surely influenced by the numerous critiques addressed by anime fans (personal communication, February 2011).

32. UFO Robo Gurendaizā (1975-1977): Directed by Tomoharu Katsumata. Japan. Atlas UFO Robot Grendizer (1979-1980): American version of UFO Robo Gurendaizā (1975-1977). UFO Robot Goldrake (1978-1980): Italian version of UFO Robo Gurendaizā (1975-1977).

33. Hauru no ugoku shiro (2004): Directed by Hayao MiYazAKi. Japan. Howl's Moving Castle (2004): American version of Hauru no ugoku shiro (2004). Il castello errante di Howl (2004): Italian version of Hauru no ugoku shiro (2004).

34. Kōdo Giasu - Hangyaku no Rurūshu (2006-2007): Directed by Gorō Taniguchi. Japan. Code Geass: Lelouch of the Rebellion (2008-2009): American version of Ködo Giasu - Hangyaku no Rurūshu (2006-2007). 
Code Geass: Lelouch of the Rebellion (2009-2010): Italian version of Kōdo Giasu - Hangyaku no Rurūshu (2006-2007).

35. Kōdo Giasu - Hangyaku no Rurūshu R2 (2008): Directed by Gorō TANiguchi. Japan. Code Geass: Lelouch of the Rebellion R2 (2008-2009): American version of Kōdo Giasu - Hangyaku no Rurūshu R2 (2008).

Code Geass: Lelouch of the Rebellion R2 (2009-2010): Italian version of Kōdo Giasu - Hangyaku no Rurūshu R2 (2008).

36. Tengen toppa Guren Ragan (2007): Directed by Hiroyuki Imaishi. Japan. Gurren Lagann (2008): American version of Tengen toppa Guren Ragan (2007). Sfondamento dei cieli Gurren Lagann (2009-2010): Italian version of Tengen toppa Guren Ragan (2007).

\section{REFERENCES}

Baricordi, Andrea, De Giovanni, Massimiliano, Pietroni, Andrea, et al. (2000): Anime: A Guide to Japanese Animation (1958-1988). Montreal: Protoculture.

Billiani, Francesca (2007): Modes of Censorship and Translation. National Contexts and Diverse Media. Manchester: St. Jerome.

Brown, Steven T. (2008): Cinema Anime. New York: Palgrave Macmillan.

BUCARIA, Chiara (2009): Translation and censorship on Italian TV: an evitable love affair? VIAL. 6:13-32.

D’Agostino, Nicola (2005): La censura nei fumetti e nei cartoni animati giapponesi in Italia. Breve cronistica di pratiche, fenomeni e casi nell'adattamento delle produzioni nipponiche nel nostro paese. Visited on 21 January 2011, <http://cyberfreedom.olografix.org/doc/ dagostino.pdf $>$.

Díaz Cintas, Jorge and Orero, Pilar (2010): Voiceover and dubbing. In: Yves Gambier and Luc VAN Doorslaer, eds. Handbook of Translation Studies. Volume 1. Amsterdam/Philadelphia: John Benjamins, 441-445.

FAWCETt, Peter (2003): The manipulation of language and culture in film translation. In: María Calzada Pérez, ed. Apropos of Ideology. Translation Studies on Ideology - Ideologies in Translation Studies. Manchester: St. Jerome, 145-163.

GAMBIER, Yves (2002): Les censures dans la traduction audiovisuelle. TTR. 15(2):203-221.

Grieveson, Lee (2004): Policing Cinema. Movies and Censorship in Early-Twentieth-Century America. Berkeley / Los Angeles: University of California Press.

Huesmann, L. Rowell and Eron, Leonard D., eds. (1986): Television and the Aggressive Child: A Cross-National Comparison. Hillsdale: L. Erlbaum Associates.

Huesmann, L. Rowell and Moise, Jessica (1996): Media violence: a demonstrated public health threat to children. The Harvard Mental Health Letter. 12:5-7.

JAnsen, Peter, ed. (1995): Translation and the Manipulation of Discourse. Leuven: CETRA, Research Center for Translation, Communication and Cultures.

Katan, David (2010): Il doppiaggio del cartone animato tra imposibilità e successo. In: Gian Luigi De Rosa, ed. Dubbing Cartoonia. Casoria: Loffredo Editore, 11-28.

Licari, Anita and Galassi, Gianni G. (1994): Problemi di doppiaggio nei film di Eric Rohmer. In: Raffaella Baccolini, Rosa Maria Bollettieri Bosinelli and Laura Gavioli, eds. Il doppiaggio. Trasposizioni linguistiche e culturali. Bologna: CLUEB, 157-167.

Mathews, Tom Dewe (1994): Censored. The Story of Film Censorship in Britain. London: Chatto and Windus.

Murray, John P. (1997): Media violence and youth. In: Joy D. Osofsky, ed. Children in a Violent Society. New York: The Guilford Press, 72-96.

Nakamura, Ichiya and Onouchi, Megumi, eds. (2006): Nihon no Pop Power [Japan's Pop Power]. Tokyo: Nihon Keizai Shonbusha.

Napier, Susan J. (2001): Anime. From Akira to Princess Mononoke. New York: Palgrave Macmillan. 
Napier, Susan J. (2005): Anime. From Akira to Howl's Moving Castle. New York: Palgrave Macmillan.

Ní Chuilleanáin, Eiléan, Ó Cuilleanáin, Cormac and Parris, David, eds. (2008): Translation and Censorship. Patterns of Communication and Interference. Dublin: Four Courts Press.

O'Hagan, Minako (2006): Manga, anime and video games: Globalizing Japanese cultural production. Perspectives: Studies in Translatology. 14(4):242-247.

PARINI, Ilaria (forthcoming): Translation and taboo in audiovisual works. In: Susana BAyó Belenguer, Eiléan Ní Chuilleanáin, and Cormac Ó Cuilleanáin, eds. Translation Right or Wrong. (Translation: Right or Wrong? Dublin, 6-7 March 2009) Dublin: Four Courts Press.

Pavesi, Maria and Malinverno, Annalisa (2000): Sul turpiloquio nella traduzione filmica. In: Christopher TAYlor, ed. Tradurre il cinema. Trieste: La Stea, 75-90.

Pellitteri, Marco (2002): Mazinga Nostalgia: Storia, valori e linguaggi della Goldrake-generation. Rome: Castelvecchi editore.

Phoenix, Dorothy Ann (2006): Protecting Young Eyes: Censorship and Moral Standards of Decency in Japan and the United States as Reflected in Children's Media. B.A. thesis, unpublished. Cambridge: Massachussets Institute of Technology. Visited on 20 February 2011, $<$ http://dspace.mit.edu/bitstream/handle/1721.1/35076/71249564.pdf?sequence=1 $>$.

RundeE, Christopher (1999): Publishing translations in Mussolini's Italy: A case study of Arnoldo Mondadori. Textus. 12(2):427-442.

RundLE, Christopher (2000): The censorship of translation in fascist Italy. The Translator. 6(1):6786.

Rundle, Christopher (2010): Publishing Translations in Fascist Italy. Oxford: Peter Lang.

Rundle, Christopher and Sturge, Kate, eds. (2010): Translation under Fascism. Basingstoke: Palgrave Macmillan.

Saito, Minako (1998): Koittenron. A Theory of One Red Flower. Tokyo: Village Center.

Sturge, Kate (1999): A Danger and a Veiled Attack. Translating into Nazi Germany. In: Jean Boase-Beier and Michael Holman, eds. The Practices of Literary Translation. Constraints and Creativity. Manchester: St. Jerome, 135-146.

Sturge, Kate (2002): Censorship of Translated Fiction in Nazi Germany. TTR. 15(2):153-169.

Venuti, Lawrence (2008): The Translator's Invisibility: A History of Translation. London: Routlege. 